\title{
Corpo-prostituto em carreira e relações homoeróticas
}

\author{
Male Prostitute Body in Professional and Homoerotic Relations \\ Cuerpo prostituto en carrera y relaciones homoeróticas
}

Dorinaldo dos Santos Nascimento*

\section{Resumo}

Por meio do corpo, o sexo pode ser lugar de ganho e de negócio, o que o configura em uma dimensão mercadológica e em espaço de circulação do desejo. Nesse sentido, o objetivo deste trabalho é analisar as representações ficcionais do corpo-prostituto em carreira do personagem Benício (garoto de programa, gigolô) e as relações estabelecidas entre ele e os clientes homossexuais no romance As flores do jardim da nossa casa (2007), de Marco Lacerda. Para tanto, nosso aporte teórico-crítico buscou uma aproximação e interlocução entre estudos literários e culturais. As análises empreendidas permitiram-nos asseverar que há: um processo generificado no/do negócio do sexo por meio da monetização da masculinidade hegemônica; a explicitação de problemáticas sociais na instância da saúde pública pela vulnerabilidade de contaminação às infecções sexualmente transmissíveis/HIV/aids; e a ocorrência de relações e jogos de poder entre os sujeitos coparticipantes do mercado do sexo evidenciados por tensões e cruzamentos etário (jovem/velho), somático (padrões de corporeidade hegemônica/corpos abjetos) e socioeconômico (classes sociais díspares).

Palavras-chave: corpo-prostituto, homoerotismo, Marco Lacerda.

\begin{abstract}
Through the body, sex can be a place of profit and business, configured with both a market dimension and as a space for the circulation of desire. In this sense, the objective of this paper is to analyze the fictional representations of the working male prostitute body of the character Benício (call-boy, gigolo) and the relationships he establishes with his homosexual clients in the novel As flores do jardim da nossa casa (2007), by Marco Lacerda. For this, our theoretical-critical contribution sought an approximation and interlocution between literary and cultural studies. The analyses carried out allowed us to assert that there is: a gendered process in / of the sex business through the monetization of hegemonic masculinity; an explication of societal ills pertaining to public health and the vulnerability of contamination by sexually transmitted infections $\mathrm{HIV} /$ aids; and an occurrence of power relations and games between the subjects participating in the sex market evidenced by tensions and crossings age (young/old), somatic (patterns of hegemonic corporeality/abject bodies) and socioeconomic (different social classes).
\end{abstract}

Keywords: male prostitute body, homoerotism, Marco Lacerda.

\section{Resumen}

A través del cuerpo, el sexo puede ser un lugar de ganancias y negocios, lo que lo configura en una dimensión de mercado y en un espacio para la circulación del deseo. En este sentido, el objetivo de este trabajo es analizar las representaciones ficticias del cuerpo prostituto de carrera del personaje Benício (chapero, gigoló) y las relaciones establecidas entre él y los clientes homosexuales en la novela As flores do jardim da nossa casa (2007), de Marco Lacerda. Para esto, nuestra contribución teórico-crítica buscó una aproximación e interlocución entre los estudios literarios y culturales. Los análisis realizados nos permitieron afirmar que existe: un proceso de género en / del negocio del sexo a través de la monetización de la masculinidad hegemónica; la explicación de los problemas sociales a nivel de salud pública debido a la vulnerabilidad de la contaminación a las infecciones de transmisión sexual/VIH/SIDA; y la aparición de relaciones de poder y juegos entre los sujetos que participan en el mercado sexual evidenciado por tensiones y cruces edad (joven/viejo), somático (patrones de corporeidad hegemónica/cuerpos abyectos) y socio-económico (diferentes clases sociales).

Palabras-clave: cuerpo-prostituto, homoerotismo, Marco Lacerda.

\footnotetext{
Universidade Federal de Uberlândia (UFU), Uberlândia, MG, Brasil. (Dorcid.org/0000-0002-3520-2679. E-mail: naldo.nascimento@ufu.br
} 
Pelo poder demiúrgico do narrador, no romance As flores do jardim da nossa casa, de Marco Lacerda (2007), ${ }^{1}$ Benício representa o sujeito ficcional que constrói uma carreira enquanto corpoprostituto. ${ }^{2} \mathrm{O}$ personagem não apenas faz da prostituição uma carreira, mas exaure ao máximo as potencialidades possíveis do seu intercambiável e mercantilizável corpo ao transitar por diferentes territórios de prostituição - como ruas, saunas, boates - e por modalidades díspares de experiências do corpo-prostituto: de garoto de programa a gigolô. Isso ocorre até que o processo de exaustão do personagem culmina no abandono da prostituição e na incursão no submundo do crime, levando-o à morte.

O corpo, para Benício, torna-se um princípio fundante, evidentemente, para o êxito em sua carreira como corpo-prostituto e para a forma como ele busca inscrever-se no mundo. A corporeidade do personagem, marcada pela robustez muscular, encontra ressonância em clientes homossexuais que o valorizam e procuram-no em virtude dessa constituição corpórea. Assim, o narrador o descreve:

A camisa, desabotoada sem prudência, deixava à vista as profundidades do tórax, com mangas estrategicamente enroladas para permitir a visão dos músculos inquietos dos bíceps [...] no vestiário da sauna, enquanto desafivelava o cinto com nonchalance ensaiada, deixando mais músculos saltarem de dentro da calça para serem exibidos aos clientes ávidos por surpresas que aguardavam na penumbra das termas. O corpo branco e teso era coberto por uma penugem leve, quase invisível, disfarçando as sardas que se espalhavam pela pele, oriundas de um parentesco com holandeses, remoto mas comprovado. Os sinais mais visíveis de masculinidade, por estranho que pareça, vinham do movimento firme dos músculos da bunda e de uma camada mais espessa de pelos que saía do púbis e percorria $o$ tórax bem torneado, estendendo-se até o peito e espalhando-se pelo busto, de onde saltavam dois sólidos mamilos (Lacerda, 2007, p. 20, grifo nosso).

O olhar voyeur do narrador, por meio da reiteração insistente dos músculos, faz o desenho anatômico do corpo-sexual de Benício disponível no mercado do sexo. Esses músculos, de tão intumescidos, inquietos, vívidos, possuindo propriedades como profundidade e solidez, saltam ou quase rompem a roupa sob o imperativo de serem exibidos, personificando desse modo a identidade narcísica masculina do personagem pela hipérbole muscular. Além disso, é digno de nota como a indumentária escolhida coopera para o exibicionismo e a valorização dos músculos, já que a camisa está posta em semiabertura ("sem prudência"), com suas mangas "estrategicamente enroladas", os músculos saltando da "calça", o que possibilita entender que a peça é justa ao corpo, marcando as formas dos membros inferiores. Ou seja, as roupas, para o personagem, extrapolam o utilitarismo estabelecido pela cultura como forma de se cobrir. Elas são a segunda pele produzida para o agenciamento erótico-sexual na atividade de prostituição.

No trecho escolhido, convém apontar também o fato de que o narrador transparece certa percepção heternormativa ao apontar estranheza no movimento muscular dos glúteos. Estes, nessa visão, são impensáveis como signo de masculinidade do que marcaria o sujeito masculino

\footnotetext{
${ }^{1}$ Jornalista e escritor mineiro, autor de três romances: Favela high-tech (1993), resultado de sua experiência como correspondente internacional no Japão, o qual foi reeditado várias vezes e, apesar das condições do mercado editorial de literatura em nosso país, é um best seller. O romance, que teve os direitos de filmagem para o cinema comprados pela Gullane Filmes, de São Paulo, encontrase em desenvolvimento com o título Neon river, sob direção de Karim Aïnouz. Após o livro de estreia, Lacerda publicou Clube dos homens bonitos (1996), também com boa vendagem, cuja história é inspirada em seu ofício de jornalista no período em que esteve nos Estados Unidos. Posteriormente, lançou o romance As flores do jardim da nossa casa (2007), indicado para o Prêmio Jabuti em 2008, tendo sido lançado em 2018 em Portugal pela editora Chiado Books.

${ }^{2} \mathrm{O}$ termo corpo-prostituto foi pensado para funcionar como uma noção operacional no desenvolvimento do trabalho. A inserção do hífen na formação do termo tem o propósito de produzir um substantivo composto (processo de composição por justaposição), de modo a desfazer a condição de adjetivo da palavra "prostituto", que, estando ao lado de "corpo" (sem hífen), serviria como referência aos dois gêneros: o corpo prostituto masculino ou feminino. Por outro lado, ao propormos o termo como substantivo composto (com hífen), buscamos assinalar o gênero como marcador do sujeito masculino que se prostitui, o que é categoria fundamental para análise. Além disso, adotar o vocábulo "prostituto" como forma de posicionamento investigativo contraria a uma ordem histórica e social falocêntrica, que impôs ideologicamente ao longo do tempo o uso do termo "prostituta" com toda carga estigmatizante ao ser feminino concomitante ao apagamento do termo no masculino ("prostituto"). Sendo assim, o termo corpoprostituto contempla uma multiplicidade de práticas e de sujeitos que monetizam seus corpos, tais como: bagaxa, garoto de programa, boy de programa, michê, prostituto, gigolô, acompanhante e toy boy.
} 
viril, já que, nessa ordem de pensamento, só os homens homossexuais, pela prática homoerótica do sexo anal, poderiam ser destacados por esta parte do corpo.

Diante da específica corporeidade do personagem, pensamos que a robustez muscular de Benício se configura pelo corpo-prostituto que se mercantiliza sob a ideia de uma masculinidade hegemônica (Connell, 1995; 1997; Connell; Messerschmidt, 2013) enquanto propriedade de um corpo viril musculoso. Essa constituição corpórea do personagem é, sem dúvida, uma produção do mercado do desenvolvimento muscular masculino, por estipular formas de cuidados e técnicas de gestão do corpo que, inscritos na "cultura do músculo", segundo Jean-Jacques Courtine, em Robustez na cultura: mito viril e potência muscular, gera nos sujeitos "uma inflação contínua do corpo, uma hipérbole viril, a excrescência muscular extrema de uma masculinidade das aparências, que não conheceu nem equivalente nem precedente na história do corpo no Ocidente" (Courtine, 2013, p. 556).

Desse modo, o corpo musculoso de Benício inequivocamente é resultante de formas de regulação dos corpos, simbolizando bem o corpo disciplinado, o "corpo-máquina", ${ }^{3}$ segundo Michael Foucault (1999, p. 179), fabricado em academias de ginástica como "uma máquina de alta performance" (Kunzru, 2009, p. 23). Constituído nesses moldes, pela musculatura hipertrofiada, o corpo de Benício pode ser concebido como uma expressão maiúscula do "ciborgue" /" ciborguiano": "um organismo cibernético, um híbrido de máquina e organismo, uma criatura de realidade social e também uma criatura de ficção" (Haraway, 2009, p. 36) do sujeito pós-moderno. Trata-se de um amálgama entre o "natural" e o "artificial", consoante ao que diz Donna Haraway (2009) em "Manifesto ciborgue: ciência, tecnologia e feminismosocialista no final do século XX", no livro Antropologia do ciborgue.

Isso nos endereça para o entendimento da dinâmica que se instaura para o consumo de corpos fabricados, moldados, (re)modelados e (re)construídos, ilustrativo no corpo-prostituto de Benício, que é produzido nos moldes conforme explicitam os teóricos. Tal fato é constatável no personagem, porque, além de ser um sujeito ficcional (frentista de posto de gasolina), que, "nas academias de ginástica que frequentava" (Lacerda, 2007, p. 25), fabrica, (re)modela, (re)constrói seu corpo, este é objeto rentável no mercado da prostituição. Logo, o corpoprostituto de Benício não se furta à subjetivação como produto mercadológico e objetificado, fonte de prazer pela via da modelagem palpável em músculos.

Benício atinge o auge de sua carreira como garoto de programa portando a corporeidade ciborgue por intermédio da hipérbole muscular, após obter visibilidade em revista nacional para o público gay. Em virtude disso, os "melhores clientes faziam questão de serem vistos ao lado do bonitão com um par de bíceps que intumesciam ao mero erguer de uma latinha de cerveja" (Lacerda, 2007, p. 25). Convém endossarmos que Benício não apenas obteve o ápice da sua trajetória como corpo-prostituto com a configuração corpórea assinalada, mas também fez da prostituição uma carreira.

Se pensarmos que carreira pressupõe um movimento ascendente, Benício não destoa disso, ao contrário, ele dá os primeiros passos de sua trajetória como garoto de programa na chamada "baixa prostituição". É no território arriscado e vulnerável da rua que o personagem começa a sua carreira:

No vale-tudo de um comércio sem lei ele era tentado, em troca de cachês polpudos, a participar de aventuras suicidas. A mais frequente, conhecida como "roleta-russa", era fazer sexo anal sem camisinha. Como aprendera nos programas de auditório da tevê, quem quer ganhar uns trocados topa tudo por dinheiro. Não haveria de ser diferente com um garoto de programa. Mesmo vivendo num tempo de pestes transmissíveis, Benício topava [...] Bastava uma roleta-russa para encurtar a romaria solitária. Uma única roleta e Benício faturava o que normalmente só conseguia depois de vários programas que se

\footnotetext{
${ }^{3}$ Segundo o filósofo francês, a noção de utilidade e eficiência passou a regular os processos biológicos da vida, dando forma ao "corpo máquina". Pôde-se, a partir de então, "consertar, corrigir, substituir o que não funcionava, extrair o que havia de excesso, fazendo com que diferentes procedimentos funcionassem de forma complementar para manter os corpos submetidos a uma norma" (Fraga, 2003, p. 136).
} 
arrastavam até altas horas. Mas foram poucas as vezes em que ele teve essa sorte (Larcerda, 2007, p. 29-30).

Benício figura, a partir desse excerto, pela força de uma simbólica metáfora: a da roletarussa, cuja voz narradora faz referência a conteúdos televisivos de massa ("topa tudo por dinheiro") para aludir o poder de agenciamento do dinheiro nos sujeitos. Sabe-se que na construção de uma carreira, em geral, o componente sorte, compreendido com o acaso feliz ou a contingência favorável, é importante. Benício, ainda nos passos iniciais de sua trajetória na prostituição, joga com o elemento "sorte"; e, desse modo, o personagem figura na trama enquanto metáfora da roleta-russa, tornando-se uma imagem literária produtiva, pois, ele pode ser concebido como o abismo deliberado de si.

Ao dar vazão a seu livre-arbítrio, ele, pela consciente exposição de contatos sexuais desprotegidos com corpos desejantes sem nome, simultaneamente, funde na sua pessoa elementos em combate, como o perigo e a sorte, e faz da sua existência um arriscado jogo de uma "brincadeira" macabra. Assim, é ele próprio o alvo potencial, não das balas do revólver, como no jogo original, mas o objeto vulnerável a ser mirado por possíveis agentes biológicos nefastos. Quando "brinca" de ser roleta-russa, colocando-se numa situação-limite convergente à tênue fronteira entre vida e morte, o personagem joga com a sorte, apesar de tê-la como aliada; com isso, revela parte da sua subjetividade ao se prostituir, assumindo todos os riscos advindos de sua prática.

O recorte ficcional apresentado, em razão do diálogo com a realidade sociocultural, indica que a aventura suicida do personagem está repleta de significação ao considerarmos que a ação narrativa se passa no contexto dramático do HIV/aids, quando, há aproximadamente trinta anos, o quadro epidemiológico de infecção ao vírus configurava-se como devastador. O personagem Benício, pela ficcionalização do corpo-prostituto que segue itinerários marginais, arriscados, mobilizado pela possibilidade de ganho monetário mais elevado e pelo desejo de abreviação do árduo trottoir de rua, expõe-se ostensivamente aos riscos de contaminação às infecções sexualmente transmissíveis (ISTs), sobretudo ao HIV/aids, e a referência do narrador às "pestes transmissíveis", sem dúvida, remete à "peste gay", tão emblemática na história recente dos sujeitos homossexuais. O próprio narrador, ao rememorar sua história de vida, narra os terríveis efeitos do HIV/aids no agudo período dos anos 1980, relatando a perda de vários amigos e de sua única relação afetiva vivenciada com o personagem Maurício, que também falece em decorrência da soropositividade.

Diante das antagônicas condições da prostituição de rua, Benício passa por um processo de autoconfrontação. É justamente o estado de crise interna do personagem, em decorrência do enfrentamento das vicissitudes na rua, que possivelmente funciona como propulsor de mudanças, levando-o à decisão de se prostituir migrando para o espaço da sauna, que lhe possibilitaria ascensão e benesses materiais exponenciais. A propósito, a prostituição em sauna figura como núcleo central da carreira de Benício, pois é na territorialidade desse local de homossociabilidade $-^{4}$ o qual disponibiliza a prática da prostituição como serviço ofertado que o personagem atinge o ápice de sua trajetória como corpo-prostituto.

A sauna, outro lugar convocado enquanto cenário diegético para Benício se prostituir, é "discretamente localizada numa rua no centro da cidade" (Lacerda, 2007, p. 19, grifo nosso) e, na "penumbra das termas" (Lacerda, 2007, p. 20), circulam os personagens homossexuais descritos pelo narrador, os quais analisaremos posteriormente. Como local sui generis marcado pela constituição de um espaço de homossociabilidade, incrustado no seio de uma sociedade regida por valores heteronormativos, destaca-se desse modo a aparência externa da sauna, marcada pela discrição, responsável por não transparecer a natureza das atividades realizadas no local, bem como a ambiência penumbral da ordem do que deve ser escondido. Esse ambiente ficcional da sauna permite um diálogo com a ideia de "contra-casa", pensada por James Naylor

\footnotetext{
${ }^{4}$ As saunas, como espaços para a prostituição masculina, seriam correspondentes aos bordéis, puteiros, termas, casas de massagem ou clínicas de estéticas em que ocorrem, mais tradicionalmente, a prática da prostituição feminina (Santos, 2016).
} 
Green em Além do carnaval: a homossexualidade masculina no Brasil do século XX. Segundo ele, a "contra-casa" seria

outro espaço fechado onde os homens [podem] interagir livremente e que [serve] como alternativa à família tradicional [...] esses espaços de "contra-casa", localizados entre o privado (a casa) e o público (a rua), protegendo seus frequentadores de uma sociedade agressiva e hostil às práticas que se [realizam] ali dentro (Green, 2000, p. 33).

À luz dessa ideia, numa perspectiva contextualizadora histórica, as saunas como "contracasa" seriam uma mutação das antigas "casas de banho" (Figari, 2007, p. 2019). O pesquisador assinala que as casas de banho, embora explicitassem nos anúncios comerciais a sua "decência", eram lugares onde era permitido deixar à vista parte do corpo ou ficar totalmente nu diante de pessoas do mesmo sexo sem despertar suspeitas, com possibilidade de compartilhar o mesmo camarote. Quer dizer, um espaço mais propício àqueles homens que desejavam ter relações com outros homens sem a exposição ostensiva da "pegação" nas ruas. Barreto (2017) menciona o fato de as casas de banho, futuras saunas masculinas, serem espaços da cidade que foram se delineando como especificamente homoeróticos, ou seja, sendo reconhecidos por um grupo como lugar de encontro com outros homens. Esses locais não surgem especificamente como homoeróticos, já que, para o restante da sociedade, cumpre outras funções.

Na cartografia da sauna, pinçada pelo olhar do narrador, são registrados, sobretudo, espaços em que predominam o jogo de sedução e os códigos não verbais, por meio da apresentação/exposição/manipulação do corpo-prostituto evidenciada na narrativa a partir da "nonchalance" teatral de Benício, ao tirar a roupa no vestiário - lugar estratégico para a produção e captação de olhares desejantes/desejados do corpo-sexual a ser vendido -, assim como no "balcão do bar" ocorre investimento em um repertório gestual e troca de olhares. Conforme assinala Daniel Kerry dos Santos (2016) em Homens no mercado do sexo: fluxos, territórios e subjetivações,

$\mathrm{O}$ olhar ${ }^{5}$ é o primeiro contato, a primeira significação que transcorre nesses tipos de encontros. Não se trata do olhar de um flerte qualquer, mas de um olhar erótica e sexualmente interessado que afeta os dois envolvidos e os envolve em um outro caminhar (Santos, 2016, p. 127).

Além dos jogos de sedução que apelam para o agenciamento erótico-sexual por meio de artifícios não verbais, a voz narradora afirma que Benício é: "Heterossexual por inclinação e garoto de programa por profissão" (Lacerda, 2007, p. 19). Essa dicotomização do personagem, além de revelar o espelhamento da homo(sexualidade) problemática do narrador em sua criatura, permite-nos um diálogo entre ficção e discussões socioculturais. Essa separação entre a orientação sexual do sujeito prostituto de um lado e a prática da prostituição masculina com um público homossexual de outro endereça-nos à noção atualmente denominada como gay for pay, oriunda do cinema pornográfico gay. Essa ideia é estendida ao universo da prostituição masculina, cujos garotos de programa, apesar de assumirem publicamente manterem relações sexuais com homossexuais por dinheiro, reafirmam a sua heterossexualidade compulsória.

De acordo com a historiadora Florence Tamagne (2013), no capítulo "Mutaçoes homossexuais" presente no livro História da virilidade: a virilidade em crise? Séculos XX-XXI, o qual trata de questões sobre "masculinidades pós-modernas", a origem da expressão gay for pay remonta ao contexto da indústria pornográfica voltada para o público gay. Segundo a pesquisadora,

Com a profissionalização, o pornô gay se tornou mais impessoal. Muitos atores eram heterossexuais e só aceitavam participar desses filmes por dinheiro (gay for pay). Uma hierarquização dos atores se desenhou então: no alto, aqueles que se reconheciam como "ativos", ou seja, "heterossexuais"; na base, aqueles que se reconheciam como "passivos" (Tamagne, 2013, p. 450).

\footnotetext{
${ }^{5}$ Esse "ritual" marcado pela leitura e decodificação de olhares, de um ponto de vista semiótico, tem profunda relação com o flerte homoerótico, que historicamente precisou passar dissimulado do olhar público e ainda hoje precisa, em alguns contextos, ser feito de modo cauteloso (haja vista o risco iminente de retaliação homofóbica). Em virtude disso, precisou inventar agenciamentos próprios para efetivar e dar expressão ao desejo que não se deixa capturar por prescrições heteronormativas (Santos, 2016, p. 127).
} 
À luz desse pensamento, pela interface literatura e cultura, podemos pensar em Benício, a partir da perspectiva e do modo de representação operado pelo narrador, como um personagem configurado enquanto gay for pay. Benício, assim como boa parte dos garotos de programa, para além da ficção, constitui o corpo-prostituto hiperviril entrando no jogo de encenação pela incorporação de um padrão rentável. Sem abrir mão dos protótipos gestuais e dos discursivos da masculinidade hegemônica em sua apresentação diante dos clientes, eles, segundo Perlongher (1987), "parecem mais másculos que o mais heterossexual dos homens, os michês são quase caricatos na sua masculinidade. Descobriram que sendo assim têm mais chance de se comercializarem" (1987, p. 100, grifo nosso). Tal fato os configura, desse modo, em simulacros, pura "exacerbação paródica do modelo majoritário de Homem com H socialmente dominante" (Perlongher, 1987, p. 60).

Nesse contexto, vejamos um recorte narrativo de um dos personagens que paga pelo sexo, o qual foi escolhido pelo jovem garoto de programa:

O olhar de Benício recai então sobre a presa ideal para abrir os trabalhos: um homem em idade avançada - algo entre os 70 e a morte -, sentado ao fundo do salão. Embora não o tivesse visto, aproxima-se como se o conhecesse de longa data. Com a toalha na mão, exibindo os dotes físicos, contorna a cadeira onde o ancião esbanja abandono e fadiga, mas nenhum sinal que se possa entender como desejo sexual. O que esse senhor parece estar procurando, penso com meus botões, é alguém a quem possa oferecer um drinque e jogar conversa fora, antes de retornar à solidão de sua casa. Engano. Com a determinação de quem sabe onde põe os pés, Benício planta-se de pé atrás da cadeira onde o velho está sentado e reanima seu corpo alquebrado com uma massagem tão dramática que mais parecem golpes de karatê. Em minutos devolve ao ancião o vigor de um adolescente. Os dois jantam - Benício devora o prato com apetite de lenhador, conversam amenidades e sobem juntos para as cabines privativas, no segundo andar, onde tudo acontece. $O$ vetusto senhor sobrevive à orgia, mas volta com os cabelos desgrenhados de quem deu um show de dança do ventre no banco de trás de um Fusca (Lacerda, 2007, p. 22).

Pelo discurso operado pela voz narrativa, notamos no trecho como o corpo rentável de Benício, em face também do personagem pagante pelo sexo, realiza um "roteiro" com cinco fases distintas convergentes, evidentemente, com a transação sexual. No primeiro momento, ocorre a aproximação preliminar entre corpo-prostituto e cliente. Para atrair a atenção inicial, o garoto de programa vale-se de um corpo que simula amistosidade e familiaridade, a partir da criação de um espaço artificial de proximidade, recorrendo ao artifício de aproximar-se do desconhecido cliente como "se o conhecesse de longe data". Nesse sentido, presumimos ter havido algo, como cumprimento, sorriso e falas agradáveis.

O momento seguinte, servindo ao propósito de excitação, evidencia o apelativo agenciamento erótico-sexual realizado pelo corpo-prostituto por meio da exibição do seu corposexual, que, apoiado no dress-code do local sem a toalha, exibe os "dotes físicos". Tal expressão é eufêmica e sarcástica pela possível ambiguidade, já que, pelo uso do plural, tanto se refere ao conjunto anatômico musculoso quanto ao pênis do personagem, conforme vocabulário corrente na prostituição. Assim, seu dote ${ }^{6}$ - cujo termo ressignificado no mercado do sexo remete ao falocentrismo, ao ponto de o órgão genital masculino ser alçado à condição de um bem, um patrimônio e um capital de quem o possui, caso seja grande - torna-se ainda mais valioso.

O terceiro momento refere-se ao ato da massagem, quando Benício está pelado e - é necessário sublinhar isso, pois a nudez contribui como elemento de excitação sexual - coloca-se atrás da cadeira do senhor, propondo a massagem de maneira segura no jogo de sedução empreendido por ele, com "a determinação de quem sabe onde põe os pés". Mas é pertinente também falar das mãos, pois o garoto de programa realiza, pela experiência tátil, a ativação do corpo "alquebrado" do cliente por meio da massagem. O momento seguinte acontece em dois atos aproximativos entre os sujeitos interessados em negociar o sexo no específico espaço da

\footnotetext{
${ }^{6}$ Há sites que anunciam garotos de programa e, na descrição dos anunciados, utilizam o termo "dote" como característica para fazer referência ao tamanho do pênis. Tal fato pode ser constatado no seguinte portal: http://www.eliteboy.com.br/cidade/salvador-ba.
} 
sauna: o compartilhamento de presenças pelo jantar concomitante à conversa, que possibilita o pacto oral entre as partes envolvidas no negócio do sexo - que diz respeito ao conteúdo, duração e valor do programa, por exemplo. Isso ocorre até que o "roteiro" do corpo intercambiável de Benício segue para o seu epílogo com o cliente pelo sexo consumado.

No trecho citado anteriormente, pela linguagem e pelo modo de representação, o personagem pagante pelo sexo possui relevo. Preliminarmente, ele é enxergado, pela ótica do narrador, como uma "presa ideal", porque consegue ser o objeto de ataque do "macho" predador constituído pelo garoto de programa, além de ser tido como "ideal", segundo a perspectiva discriminatória, agressiva e desrespeitosa do narrador, devido ao fato de ser um homem "ancião", "senhor", "velho", "vetusto", construído negativamente enquanto sujeito não desejante/não desejado em "idade avançada" e presumivelmente de fácil manipulação no ato sexual, pois estaria próximo da "morte". Ademais, ele é possuidor de poder financeiro elevado, beneficiando a quem lhe tirar do esquecido "fundo do salão", onde seu corpo "esbanja abandono e fadiga", o qual pode, no máximo, contentar-se com o divertimento de beber e conversar antes de render-se "à solidão de sua casa".

O narrador admite um suposto autoengano quanto ao personagem velho não ser um sujeito desejante/desejado. Porém, contraditório e inconsistente, é sombreado posteriormente pelo espírito de chacota, do sarcasmo e da zombaria, seja por atribuir ao personagem o enganoso e irônico "vigor de um adolescente" já que ele, segundo o narrador, não morreu durante o ato sexual ("sobreviveu"), seja pela descrição debochada pelo ridículo comparativo e insólito na sequência final do excerto.

A partir da representação da voz narradora, que, sem dúvida, reflete o contexto sociocultural para além da ficção, ao sujeito homossexual velho é infligido o lugar de abjeto deserotizado, que só consegue gozar sexualmente pagando outros corpos desejados. Essa compreensão é endossada pelo antropólogo Júlio Assis Simões (2004) em "Homossexualidade masculina e curso da vida: pensando idades e identidades sexuais", quando diz:

[...] nesse cenário marcado pelo hedonismo complacente e pela obsessão com atributos físicos capazes de suscitar atração e desejo, em que tudo parece girar em torno de um mercado sexual por critérios de juventude e beleza, não haveria lugar para pessoas de mais idade, que carregariam os estereótipos derivados da depreciação de sua atratividade como parceiros sexuais desejáveis e da decorrente marginalização pelos mais jovens. Aos mais velhos, restaria pagar para desfrutar de companhia fugaz e arriscada (Simões, 2004, p. 418).

Além do personagem idoso, há outros corpos desejantes no cenário da sauna, registrados pelo narrador. Alguns, como o jovem e calvo executivo, outros descritos, como "divindade rococó" fumando absortamente, não interessam a Benício, pois, segundo ele: "Gays nessa faixa de idade pagam mal e querem ir às vias de fato rápido demais" (Lacerda, 2007, p. 21). Sua fala indicia qual o perfil e parte do modus operandi mais rentável para ele no sentido de obtenção de maior volume monetário de determinados clientes considerados pelo personagem abjetos sexuais, os quais se propõem a pagar acima do esperado, bem como aponta para o desejo dele de evitar ao máximo o corpo a corpo sexual com clientes mais jovens, os quais necessariamente exigiriam maior empenho e desgaste na realização do programa.

Seguindo sua estratégia de trabalho sexual, Benício avança em direção a outro personagem cliente:

Sem perder tempo, Benício dirige-se ao próximo alvo, um quarentão obeso protegido na penumbra de uma mesa atrás de uma pilastra. Nesses tempos em que a palavra diet tornou-se mantra de gerações ao redor do planeta, gordura é sinônimo de fracasso. No universo homossexual a tirania é ainda maior. A caprichosa estética gay elevou o ideal apolíneo a patamares inalcançáveis. Ser um homossexual gordo significa não ser tolerado e, pior, não ser notado. Bastaram algumas palavras atenciosas para deixar o gorducho num estado de exaltação que nem dois copos de conhaque conseguiriam apaziguar. Em dez minutos Benício nocauteava a segunda presa da noite (Lacerda, 2007, p. 22). 
O personagem pagante pelo sexo nessa passagem acumula uma tríplice carga de estigmatizações: gordo, não jovem e homossexual. Essa é uma configuração disfórica do personagem plasmada pela linguagem do narrador, já que ele aparece no espaço da sauna marginalizado, isolado e excluído na "penumbra de uma mesa atrás de uma pilastra" como algo da completa abjeção. Por isso, não é fortuito o fato de ele ser identificado pelo significante depreciativo "gorducho". A acentuada sensação de alijamento no personagem desdobra-se em baixa autoestima e em carência ao ponto de apenas "algumas palavras atenciosas" do garoto de programa causarem um elevado efeito de excitação nele. A digressão argumentativa crítica do narrador é digna de nota, em função do estado abjeto do personagem, quanto às questões acerca da obsessão contemporânea devido à aparência corporal que rechaça os corpos adiposos. Essa obsessão parece sustentar-se na ideia de "sobressignificação do corpo" no mundo, que se materializa numa espécie de "tarefa impossível que exige tornar a trabalhar o corpo o tempo todo em um percurso sem fim para aderir a si, a uma identidade efêmera, mas essencial para si e para um momento do ambiente social" (Le Breton, 2003, p. 29).

Situação "corpólatra" de que o próprio corpo-prostituto ciborgue de Benício é integrante, na qual "os corpólatras tornam-se os próprios Pigmaliões do próprio corpo, esculpindo-o e desenhando-o ao longo dos regimes e das sessões de musculação" (Malysse, 2002, p. 82). Tal busca pelo corpo ideal, sem dúvida, radica-se em modelos abstratos, logo, inalcançáveis. Esse contexto é transfigurado no romance não só pela voz crítica do narrador, mas também pela presença do corpo-prostituto que se constitui nesses moldes e que, pelo âmbito antropológico, Cesar Sabino, (2000) em Musculação: expansão e manutenção da masculinidade, tenta compreender como as representações sociais e as práticas do universo "corpólatra" ou da "cultura somotófila" ocorrem:

Está estabelecida, nesse meio, uma cultura somotófila, na qual o corpo é o critério básico de reconhecimento e classificação, o que possibilita o fundamento de uma reciprocidade calcada em uma concepção de mundo centrada no indivíduo, típica desse determinado extrato das camadas médias urbanas. A busca do "corpo em forma" ou do "corpo perfeito" é sinônimo de busca pelo sucesso, status e dinheiro. Assim, o corpo individual é o centro do universo simbólico desse grupo. As relações sociais ficam dependentes da forma ostentada pelo corpo. As possíveis relações de cooperação ou solidariedade que venham ultrapassar o âmbito das academias se realizam, apenas - e mesmo assim raramente entre iguais na dimensão estética (Sabino, 2000, p. 64).

A voz narradora, em função do personagem homossexual gordo, profere sua fala crítica à "tirania" do mercado sexual gay - lembremos que a autoria do romance é de um sujeito homossexual escrevendo um romance de expressão homoerótica com personagens que se encaixam e que estão fora dos padrões desse mercado - hierarquicamente guiado pela estética apolínea em que, pela lógica hedonista, funciona de acordo com o que poderíamos denominar de consumo mercadológico do gozo sexual. Tal fato acontece em uma espécie de mercado do orgasmo, no qual a forma corporal musculosa construída possui um papel fundamental para a atração do parceiro a ser "consumido".

Desse modo, o corpo musculoso, no universo homossexual, tornou-se, então, um capital erótico muito valorizado, em contrapartida, o sujeito fora dessa norma corporal poderá não ser "tolerado" nem "notado", segundo endossa o discurso de narrador. No âmbito dessa discussão que envolve literatura e o atual contexto sociocultural, Trevisan (1998) lança sua visão crítica e provocadora:

[...] o culto explícito à musculatura avantajada ou body building, [é] um dos pilares do moderno narcisismo masculino. Não se trata apenas de inocentes halterofilistas ansiosos por autoafirmação. Esse tipo de inflação [fálica] chegou ao patamar do valor de troca erótica, na cena homossexual, onde a moeda de maior fetiche é a virilidade exibida na musculatura. Para alcançá-la, não se hesita em correr riscos com a ingestão de grandes doses de anabolizantes, por exemplo. Graças a essa moda, hoje não é incomum a existência de homens monstruosamente musculosos, mas que falam e agem como fadinhas, em reedições inadvertidas do mito do hermafrodita (Trevisan, 1998, p. 79). 
Entendemos que essa robustez muscular, capital erótico, construída a partir do contexto da "cultura dos músculos", contempla tanto o corpo-prostituto quanto os corpos dos homossexuais que não se prostituem, já que ambos se valem da hipérbole muscular para agenciamentos erótico-sexuais. Os gays, "monstruosamente musculosos", conforme aponta Trevisan (1998), são inclusive designados, de modo pejorativo e estereotipado no universo da homocultura contemporânea, como barbies. Estas, na nossa visão, ao reeditarem o "mito do hermafrodita", tornam-se emblemáticas, porque constituem uma simbiose resultante de uma masculinidade ressignificada a partir de um possível éthos gay ao passo que reproduzem e compartilham elementos do status quo referentes à corporalidade heternormativa. E, desse modo, revelam-se em última instância agentes de reverência e culto à masculinidade nos moldes hegemônicos.

É necessário enfatizar que os personagens idoso e gordo representados pelo narrador só conseguem o gozo sexual pelo capital despendido por eles. Isso denota o fato de que a prática dissidente, ilegítima da prostituição, pode cumprir um papel: possibilitar aos corpos abjetos gozarem sexualmente; de outro modo, não haveria saída para eles nesse aspecto. Em suma, diante de valores normativos etários e de padrões corporais construídos na cultura convergentes ao alijamento de corpos que não despertam atenção, é necessário que estes indesejados ascendam à condição de corpos em gozo sexual recorrendo-se à prostituição. Caso contrário, permanecerão no lugar da invisibilidade, de exclusão e de isolamento, esbanjando "abandono e fadiga" ou na "penumbra" do esquecimento, conforme descritos pelo narrador romanesco.

Na carreira empreendida pelo personagem, assim como em outras ancoradas no corpo como instrumento de trabalho, por mais que se atinja um ápice garantidor, por determinado período, daquilo que em trajetória profissional denomina-se como estabilidade, há um elemento inexorável, o tempo. E com o corpo-prostituto em análise não é diferente, pois o tempo tornouse, segundo o narrador, um "fantasma" e o "seu maior inimigo" (Lacerda, 2007, p. 30). Nesse sentido, pelo discurso direto, o personagem explicita o sentimento de desprestígio e de decadência em sua carreira decorrentes do fator etário: "Quando passei dos 25 anos, as bichas começaram a me esnobar. Muita gente que comeu do meu prato agora cospe nele - queixou-se uma vez, desaminado com o futuro" (Lacerda, 2007, p. 30).

De fato, a juventude é um capital simbólico na prática da prostituição. Trata-se de uma juventude marcada por uma especificidade no sentido de representar o mais candente frescor, viço. Geralmente, isso assume a forma da corporeidade contígua ou imediatamente derivada da adolescência, a exemplo de Benício que, aos 17 anos, 7 já havia iniciado sua carreira como corpoprostituto e, quando passou dos 25 , estava fora do padrão etário de prestígio para permanecer nela.

Logo, a juventude, no âmbito da prostituição, é uma forte moeda de troca, pois, com frequência, os sujeitos pagantes pelo sexo são mais velhos e desejam financiar o sexo com rapazes, seguindo na direção da vampirização intergeracional, que se aproxima da ideia metafórica de "sugar" por intermédio do enlace erótico-sexual a juventude do corpo-prostituto. Este, principalmente por constituir-se como corpo-mercadoria, corpo-produto, regido pela lógica do consumo, tem o prazo de validade chancelado pelo critério da juventude mais fresca possível.

Com a perda desse primordial capital simbólico na prostituição institucionalizada, Benício é forçado a produzir outros itinerários em sua carreira. Por isso, exaure como pode seu corpo monetizável, intercambiável, e expande as experiências do corpo-prostituto, o qual, se possuísse uma pele, no momento corrente da vida dele, considerando que o narrador atribui-lhe contornos de animalidade, seria preciso trocar de pele para sobreviver e (re)formular sua carreira. $\mathrm{O}$ trocar de pele refere-se à mudança de espaços e a novos papéis assumidos pelo corpo-prostituto (gogoboy, gigolô) dele. Vejamos o desenvolvimento narrativo e os desdobramentos da nova fase na carreira do personagem:

\footnotetext{
${ }^{7}$ Diante da menoridade de Benício enquanto corpo-prostituto, é necessário sublinharmos a necessária distinção entre a prostituição exercida por sujeitos adultos (conforme ocorre na quase totalidade com o personagem em tela) da prática ilegal de exploração sexual envolvendo menores de idade e/ou indivíduos sem plena condição de consentimento e consciência de seus atos (situação exemplificada na trajetória inicial de Benício).
} 
Depois de anos acostumado às mordomias proporcionadas pelas carteiras abertas de homossexuais, Benício era forçado a contemplar o próprio ocaso sem saber o que fazer da vida [...] Benício acabou trocando as saunas por boates em locais pouco idôneos. Sob os lasers das pistas de dança, continuava suando a camisa para descolar algum. As conquistas dessa fase não foram lá muito promissoras. Uma delas, Manola, era um travesti de encruzilhada, desses que fazem operações drásticas para mudar de sexo e acabam confinados para sempre num sexo que não é deles. Benício mudou-se para o quarto-e-sala de Manola na avenida do centro e passou a ser sustentado por ela. Com longos cabelos voluntariosamente louros e seios de silicone em luta sem trégua com o decote, Manola logo começou a dar sinais de ciúmes e a controlar a vida de Benício. O pior aconteceu na noite em que o travesti chegou em casa e encontrou o companheiro com uma prostituta. [...] Manola atacou a intrusa com um castiçal barroco de ferro. Na tentativa de proteger a amiga, Benício deu um empurrão em Manola, que rolou escada abaixo com seu corpo escultural. Escapou com vida, mas virou um monte de silicone retorcido [...] fui convocado a cooperar na restauração de um travesti. Com a ajuda de um médico amigo, conseguiu internar Manola num hospital. Mas, por se tratar de um travesti, nenhum paciente quis dividir quarto com ela. - Antes, para ter quarto individual num hospital era preciso ser muito rico. Hoje basta ser travesti - refletiu Manola, agradecida. O caso acabou logo depois (Lacerda, 2007, p. 31).

A fase áurea, a partir da visibilidade da imagem ciborgue musculosa de Benício em revista e do sucesso crescente nas saunas nas quais esbanjava juventude quando era um rosto "fresco" no cenário do mercado sexual - indispensável para ele conseguir por algum tempo entrar bem no jogo das intercambialidades com homossexuais endinheirados responsáveis por "mordomias" -, é sucedida com o passar dos anos pela perda de prestígio e pela decadência ("ocaso") da carreira de garoto de programa. A despeito disso, tendo em vista o excerto, Benício permanece fazendo de seu corpo um instrumento de sobrevivência, ora dançando no território das boates enquanto gogoboy, experiência traduzida pelo narrador na metonímica expressão "suando a camisa", ora estabelecendo predominantemente relações e/ou sociabilidades tarifadas, ao encarnar a figura do gigolô com vários personagens mantenedores.

Enfatizamos que o gigolô é o corpo-prostituto em outra configuração pelo fato de envolver não apenas sexo e dinheiro/vantagens materiais simbólicas, mas também um papel de parceria dentro de uma relação pactuada. Historicamente, o gigolô remonta, na cultura grega, ao hetairekos (Leão, 2009, p. 298) ${ }^{8}$ e, em contexto anglófono, possui equivalência na designação kept boy (Scott, 2003, p. 14), que numa tradução livre é uma espécie de indivíduo masculino mantido por outro sujeito financeiramente bem-sucedido e/ou em condições materiais mais favoráveis.

A travesti Manola é uma das personagens com quem Benício faz papel de gigolô. Por isso, torna-se relevante sublinharmos que o corpo-protituto de Benício passa a ser mantido financeiramente pelo corpo abjeto de sexualidade dissidente, representado por Manola. Além disso, pela ótica do narrador, constitui um triste fim de carreira, já que a travesti é uma das "conquistas" nada "promissoras" para Benício. Cabe aqui mencionarmos como a literatura aproxima a figura do corpo-prostituto à da travesti, duas alteridades marginais que se encontram, geralmente, no universo ilegítimo da prostituição em "locais pouco idôneos".

No romance em escopo, Manola é produzida ficcionalmente por um narrador transfóbico, que imprime uma visão preconceituosa ancorada em parâmetros heteronormativos binários acerca da travestilidade/transexualidade. Pela representação literária, o narrador concebe sua personagem como "um travesti", embora faça uma alusão ao sujeito transexual que opta pela cirurgia de redesignação de sexo. Logo, isso evidencia, no âmbito da sexualidade e das questões de gênero, sua confusão quanto à indistinção entre identidade de gênero e disposição anátomo-fisiológica, discernimento que é fulcral para a compreensão dos sujeitos travestis e transexuais.

Nesse sentido, o narrador refere-se à personagem, algumas vezes, por meio de referentes no masculino ("um", duas vezes; e "o", "desses", "deles", uma vez) e faz uso de dois significantes no

\footnotetext{
${ }^{8}$ De acordo com Leão (2009, p. 298-299), no caso da hetairesis, o parceiro sustentava a pessoa (hetairekos), da qual recebia favores sexuais, mantendo com ela uma relação mais próxima e estável e aparentemente menos sujeita à promiscuidade e ao descontrole. Por isso, difere do pornos ou perporneumenos (relações sexuais casuais e efêmeras por dinheiro).
} 
feminino ("ela" e "agradecida"). Nessa perspectiva, Manola não escapa do enfoque estereotipado que a reduz a uma constituição corpórea materializada nos cabelos loiros, no implante de silicone e no corpo escultural. A travesti, além de sustentar Benício, é traída e sofre ato violento causado por ele, o que a transforma em "um monte de silicone retorcido", expressão metonímica discriminatória e debochada que aponta para o estado de quase morte da personagem.

A partir da relação entre os dois, observamos Benício enquanto um gigolô parasitário, um corpo-prostituto indiferente, desleal e desrespeitoso em relação ao corpo desejante que o mantém. Esse comportamento, a nosso ver reprovável, não ocorre apenas com a travesti Manola, como a mostra a seguinte passagem:

Na corrida contra o tempo, Benício tentou se ajeitar com um bancário aposentado. Dividiram o mesmo teto, o bancário sempre dando mostras de afeto: roupas, viagens e outros mimos. Aprisionado em seu papel de garoto de programa, Benício reagia com secura. Ao contrário das prostitutas, que incorrem na insensatez de se apaixonar - e às vezes até de se matar por amor -, para um garoto de programa essa possibilidade não existe. Mesmo sem conhecer o bancário, eu encorajava Benício a tratá-lo com um pouco mais de deferência. No dia em que o homem comemorou 55 anos, sugeri que the desse flores e o levei a uma floricultura disposto a pagar pelo presente. Ao escolher o arranjo, Benício hesitou entre rosas vermelhas, que no dicionário amoroso querem dizer paixão, e amarelas, que indicam ternura. Acabou levando rosas brancas, que não querem dizer nada (Lacerda, 2007, p. 32).

Diante desse excerto, depreendemos que a figura do gigolô, representado ficcionalmente, configura-se num corpo produzido para mercantilizar-se por intermédio de benesses materiais de várias ordens, mas incapaz de responsividade afetiva autêntica. Nessa perspectiva, chamanos atenção a visão do narrador ao construir seu gigolô como um sujeito expresso pela impossibilidade e pela incapacidade intrínsecas de envolvimento emocional. Isso ocorre, pois, nessa lógica de pensamento - muito realista, radical e estreita demais por negar inflexivelmente o possível afetar entre humanos -, o indivíduo que se "vende" ao outro estaria preso e imobilizado em um papel imutável e imune ao ato de apaixonar-se por seu mantenedor.

Fica evidenciado, no trecho mencionado, o fato de haver uma aparência de romance encenada entre os personagens, tendo em vista a frieza emotiva de Benício e a indisposição de envolvimento amoroso por parte dele. Dessa forma, esse sujeito ficcional, figurado como gigolô, representa o jogo de trocas no qual ele ocupa o lugar de corpo esvaziado de afetividade, contudo preenchido pelo poder das conveniências e da barganha que seu capital erótico-sexual (juventude, masculinidade) consegue capitalizar. Isso faz com que o narrador coloque entre os personagens a relação de equivalência entre afetividade e bens materiais, já que o personagem bancário dava demonstração de "afeto: roupas, viagens e outros mimos".

Essa configuração de corpo-prostituto ocorre de modo mais acentuado - no tangente ao distanciamento etário maior entre os envolvidos - no arranjo relacional estabelecido entre Benício e o tio do narrador, Élio Leal, um senhor de 70 anos: "a bola da vez" e a "nova aventura" (Lacerda, 2007, p. 32). Assim sendo, pela voz do discurso direto do personagem gigolô expressa-se o seguinte em relação ao seu mantenedor: "O coroa é bacana, cheio da grana [...] O cara é um senhor, e daí? Pra quem não tem onde cair morto, que nem eu, tá bom demais" (Lacerda, 2007, p. 33). A franca e honesta fala de Benício não dissimula a forma de enxergar o personagem rico (o advogado carioca, seu mantenedor) como alguém detentor daquilo que ele, de fato, não tem: dinheiro. É desse modo que lida abertamente com a relação calcada no interesse material, embora, haja uma interpelação por parte dele que assinala uma possível ideia de reserva, sombreada pela idade avançada do seu parceiro. Contudo, isso é abrandado pelo espírito do oportunismo dele ao contentar-se com os resultados das benesses materiais ao pensar sua condição de vida sem seu mantenedor ("tá bom demais").

Essas relações de intercambialidades monetarizadas entre os personagens no espaço da ficção ilustram aquilo que, no contexto sociocultural, o antropólogo Fernando Pocahy (2011) denomina como "amor romântico parodiado". Isso é postulado quando se trata das experimentações homoeróticas de homens idosos e jovens garotos de programa, nas quais a 
"conjugal/idade" reflete as relações tensas entre conjugalidade e idade e/ou diferenças geracionais, muito marcantes nessas relações. Para o pesquisador:

O amor romântico, na forma explicitamente tarifada, assim como as relações sexuais explicitamente comerciais é [sic] pensados aqui como possibilidades de viver instantes de desestabilização das recitações teatrais da heterossexualidade compulsória/obrigatória [...] Isso se faz a partir de um jogo de "descompromisso" com certos atributos de inteligibilidade que passam pela conjugal/idade, sobretudo desde aquela pensada na forma normativa dos discursos do "amor fusional" (Pocahy, 2011, p.47).

A "conjugal/idade" monetarizada - paródia do amor romântico construído culturalmente -, evidenciada no comportamento e na fala de Benício, é permeada pelo interesse, pelo cálculo e pelo aparente romance, atrelados fortemente ao aspecto etário entre os personagens. Essa configuração relacional monetarizada é mais um desdobramento da carreira do corpoprostituto de Benício. Desse modo, após trafegar pela prostituição em rua, saunas e boates (gogoboy) e viver como gigolô, o personagem emerge na trama romanesca, após mais de década (vácuo diegético) como integrante de uma quadrilha de bandidos, reencontrando o narradorpersonagem no ambiente do crime.

Em vista da trajetória empreendida por Benício, o panorama que temos vai de um corpo apolíneo desejado, estampando capa de revista nacional, ao corpo morto perfurado por balas de revólver em página policial de jornal - visibilidade da ascensão e da queda. Esse é o roteiro do corpo de Benício no espaço romanesco de Lacerda, o qual se converte também em alteridade imbuída para a existência do narrador-personagem e para a própria escritura do romance. A voz narrativa crepuscular do romance é atravessada de pesar por meio de um narrador que se apieda da subalternidade do personagem, tenta traduzir pela sua ótica de homem culto e cosmopolita os desvãos psicológicos do sujeito que socialmente é alijado e vale-se da prostituição, no caso dele, para experimentar as benesses consumistas da ordem capitalista. $\mathrm{O}$ narrador empático à precariedade existencial de Benício busca fixar uma imagem literária: o jovem personagem seria a expressão pugilista fadada à derrota, em que, em vez de punhos em riste, o próprio corpo é o instrumento de mediação na luta pela sobrevivência em um mundo hostil à sua presença.

\section{Referências}

BARRETO, Victor Hugo de Souza (2017). "Vamos fazer uma sacanagem gostosa": uma etnografia da prostituição masculina carioca. Niterói: Eduff.

CONNELL, Robert William (1997). La organización social de la masculinidad. VALDÉS, Teresa; OLAVARRÍA, José (ed.). Masculinidad/es: poder y crise. Santiago, Chile: Isis Internacional, jun. p. 31-48. (Ediciones de las Mujeres, n. 24). Disponível em: http://www.diariofemenino.com.ar/documentos/01079_00.pdf. Acesso em: 14 abr. 2018.

CONNELL, Robert William (1995). Políticas da masculinidade. Educação e Realidade, Porto Alegre, v. 20, n. 2, p. 185-206, jul./dez. Disponível em: https:// bit.ly/38mipll. Acesso em: 14 abr. 2018.

CONNELL, Robert William; MESSERSCHMIDT, James W. (2013). Masculinidade hegemônica: repensando o conceito. Revista Estudos Feministas, Florianópolis, v. 21, n. 1, p. 241-282, jan./abr. Disponível em: https:/ / bit.ly/38omnKv. Acesso em: 19 out. 2017.

COURTINE, Jean-Jacques (2013). Robustez na cultura: mito viril e potência muscular. In: COURTINE, Jean-Jacques et al. (org.). História da virilidade: a virilidade em crise? Tradução de Noéli C. de Melo e Thiago A. L. Florêncio. Petrópolis: Vozes. v. 3, p. 554-578.

FIGARI, Carlos (2007). @s outr@s cariocas: interpelaç̃es, experiências e identidades homoeróticas no Rio de Janeiro (séculos XVII ao XX). Belo Horizonte: Ed. UFMG.

FOUCAULT, Michel (1999). Vigiar e punir: nascimento da prisão. Tradução de Raquel Ramalhete. 20. ed. Rio de Janeiro: Vozes. 
FRAGA, Alex Franco (2000). Anatomias de consumo: investimentos na musculatura masculina. Educação $\mathcal{E}$ Realidade, Porto Alegre, v. 25, n. 2, p. 135-150, jul./ dez. Disponível em: https:/ / bit.ly/2U3DHfi. Acesso em: 3 mai. 2018.

GREEN, James Naylor (2000). Além do carnaval: a homossexualidade masculina no Brasil do século XX. Tradução de Cristina Fino e Cássio A. Leite. São Paulo: Editora Unesp.

HARAWAY, Donna (2009). Manifesto ciborgue. Ciência, tecnologia e feminismo-socialista no final do século XX. In: HARAWAY, Donna; KUNZRU, Hari; TADEU, Tomaz. Antropologia do ciborgue: as vertigens do pós-humano. Tradução de Tomáz Tadeu. Belo Horizonte: Autêntica. p. 33-118.

KUNZRU, Hari (2009). "Você é um ciborgue”: um encontro com Donna Haraway. In: HARAWAY, Donna; KUNZRU, Hari; TADEU, Tomaz. Antropologia do ciborgue: as vertigens do pós-humano. Tradução de Tomáz Tadeu. Belo Horizonte: Autêntica. p. 17-32

LACERDA, Marco (2007). As flores do jardim da nossa casa. São Paulo: Terceiro Nome.

LE BRETON, David (2003). Adeus ao corpo: antropologia e sociedade. Tradução de Marina Appenzeller. 5. ed. Campinas: Papirus.

LEÃO, Delfim Ferreira (2009). O sexo e a cidade: um caso de prostituição masculina (Ésquines, contra Timarco). In: RAMOS, José Augusto; FIALHO, Maria do Céu; RODRIGUES, Nuno Simões. A sexualidade do mundo antigo. Porto: Clássica; Artes gráficas. p. 293-304.

MALYSSE, Stéphane (2002). Em busca dos (H)alteres-ego: olhares franceses nos bastidores da corpololatria carioca. In: GOLDENBERG, Mirian (org.). $N u$ E vestido: dez antropólogos revelam a cultura do corpo carioca. 2. ed. Rio de Janeiro: Record. p. 79-137.

PERLONGHER, Néstor Osvaldo (1987). O negócio do michê: prostituição viril em São Paulo. 2. ed. São Paulo: Brasiliense.

POCAHY, Fernando Altair (2011). Entre vapores e dublagens: Dissidências homo/eróticas nas tramas do envelhecimento. Tese (Doutorado em Educação) - Universidade Federal do Rio Grande do Sul, Porto Alegre. Disponível em: https:// bit.ly/3kbWzmM. Acesso em: 24 mar. 2018.

SABINO, Cesar (2000). Musculação: expansão e manutenção da masculinidade. In: GOLDENBERG, Mirian (org.). Os novos desejos: das academias de musculação às agências de encontros. Rio de Janeiro: Record. p. 61-104.

SANTOS, Daniel Kerry dos (2016). Homens no mercado do sexo: fluxos, territórios e subjetivações. Tese (Doutorado em Psicologia) - Universidade Federal de Santa Catarina, Florianópolis. Disponível em: https://repositorio.ufsc.br/xmlui/handle/123456789/176690. Acesso em: 8 mar. 2018.

SCOTT, John (2003). A prostitute's progress: male prostitution in scientific discourse. Social Semiotics, v. 13, n. 2, p. 179-199, ago. Disponível em: https:// bit.ly/38mU4fp. Acesso em: 14 mar. 2018.

SIMÕES, Júlio Assis (2004). Homossexualidade masculina e curso da vida: pensando idades e identidades sexuais. In: PISCITELLI, Adriana et al. (org.). Sexualidade e saberes: convenções e fronteiras. Rio de Janeiro: Garamond. p. 415-447.

TAMAGNE, Florence (2013). Mutações homossexuais. In: COURTINE, Jean-Jacques (org.). História da virilidade: a virilidade em crise? Tradução de Noéli C. de Melo e Thiago A. L. Florêncio. Petrópolis: Vozes. v. 3, p. 424-453.

TREVISAN, João Silvério (1998). Seis balas num buraco só: a crise do masculino. Rio de Janeiro: Record.

\section{Nota}

Este artigo é decorrente de uma pesquisa de doutorado intitulada Configurações do corpo-prostituto: Gasparino Damata, Marco Lacerda e Marcelino Freire, defendida em 2019 no Programa de PósGraduação em Estudos Literários da Universidade Federal de Uberlândia. 